\title{
Integracja podmiotów edukacii w perspektywie aksjologicznej jako priorytetowe zadanie szkoły
}

\section{Integration of Education Entities in the Axiological Perspective as a Priority Task of the School}

\begin{abstract}
ABSTRAKT
Celem poniżej przedstawionego opracowania jest ukazanie istoty integracji podmiotów edukacji wokół wartości. Podstawowy problem zawiera się w pytaniu: W jakich obszarach pracy szkoły, wyrasta pilna potrzeba integracji podmiotów edukacji, by pełniej realizować funkcje szkoły, a tym samym budować przestrzeń rozszerzajqcego horyzontu aksjologicznego? W rozwiqzaniu tego problemu zastosowano metodę analityczno-syntetycznq.

Szkoła winna być postrzegana jako ważny podmioł edukacji obywatelskiej. W tym zakresie podejmowane przez szkołę zadania powinny koncentrować na zdobywaniu i przekazywaniu wiedzy i umiejętności obywatelskich uczniom poprzez doświadczenia i prakłykowanie określonych działań obywatelskich, czy też w rozwiqzywaniu problemów społecznych i lokalnych. Ważnym zadaniem szkoły również będzie podejmowanie współpracy ze środowiskiem społeczno-kulturowym. Chodzić będzie o włączanie młodzieży między innymi w realizację programów instytucjonalnych, czy też projektów działalności społeczno-obywatelskiej.
\end{abstract}

StOWA KLUCZOWE integracja społeczna, podmioty edukacii, wartości, rodzaje integracji społecznej, zadania $w$ aspekcie integracji podmiotów szkoły

\section{KEYWORDS}

social integration, education entities, values, types of social integration, tasks in the aspect of integration of school entities

SPI Vol. 22, 2019/1

ISSN 2450-5358

e-ISSN 2450-5366

DOI: 10.12775/SPI.2019.1.001

Nadesłano: 04.10.2018 Zaakceptowano: 22.03.2019

Artykuły i rozprawy 
Wynikiem analiz jest ukazanie teoretycznego zarysu integracji społecznej, ze zwróceniem uwagi na jej rodzaje; ukazanie priorytetowych zadań w aspekcie integracji podmiotów szkoły. Wyróżniono trzy zadania: integrację wokół realizacji nadrzędnego celu szkoły, integrację na rzecz budowania szkoły środowiskowej, integrację wspomagajaca edukację obywatelskq.

\section{ABSTRACT}

The purpose of the study below is to show the essence of the integration of education entities around values. The basic problem is formulated by means of the following question: In what areas of school work is there an urgent need to integrate educational entities to fully fulfill the school's functions, thereby building a space of an expanding axiological horizon. In the solution to the above problem, analytical and synthetic methods were used.

The school should be perceived as an important subject of civic education. In this respect, the tasks undertaken by the school should focus on acquiring and transferring knowledge and civic skills to students through experience and practice of specific civic activities, or on solving social and local problems. An important task the school should undertake is cooperation with the socio-cultural environment. It should be done by inclusion of young people, inter alia, in the implementation of institutional programs or projects of socio-civic activity.

The analysis shows the theoretical outline of social integration, paying attention to its types; showing priority tasks in the aspect of the integration of school entities. Three tasks were distinguished: integration around the implementation of the overarching goal of the school, integration for building an environmental school, integration supporting civic education.

\section{Integracia społeczna - zarys zagadnienia}

Pojęcie integracji jest określane takimi sformułowaniami, jak: stan koordynacji, zgodność, zharmonizowanie, wartości. W Encyklopedii aksjologii pedagogicznej czytamy: ,Integracja społeczna, ujmowana jako cecha systemu społecznego lub proces tworzenia i doskonalenia jego spoistości; stanowi właściwość systemu społecznego jako wyodrębnionej całości złożonej z rozmaitych i różnych pod względem rodzajowym 
elementów, które jako części składowe są wzajemnie współzależne i współdziałają dla osiągnięcia wyraźnie określonych celów”".

W ujęciu socjologicznym integracja oznacza ,zespolenie i zharmonizowanie elementów zbiorowości społecznej. Podstawą integracji społecznej jest intensywność i częstotliwość kontaktów między członkami danej zbiorowości oraz akceptacja obszarów wspólnych systemów wartości, norm, ocen i sposobów rozwiązywania problemów”2. Mikołaj Winiarski uważa, że termin integracja najczęściej rozumiany jest w dwóch znaczeniach. W pierwszym znaczeniu określa pewien stan właściwej struktury organizacyjnej działania zbiorowego. W drugim znaczeniu przez integrację rozumie się proces zamierzonych, świadomych działań, zmierzających do wytworzenia spójnego, zharmonizowanego wewnętrznie układu organizacyjnego i funkcjonalnego ${ }^{3}$.

Integracja jest wpisana w świat wartości. W wielu propozycjach interpretacyjnych, dotyczących zakresu i treści integracji, podnoszony jest problem funkcjonowania wartości w różnych jego formach: jako wartości postulowanych, uznawanych, odczuwanych i urzeczywistnianych. Podniesienie w tym miejscu problemu miejsca i roli wartości w procesie integracji wydaje się zasadne ze względu na transformację celów edukacyjnych, w których wdrażanie do przestrzegania, rozumienia i urzeczywistniania wartości traktowane jest jako cel nadrzędny. Władysław Jacher uważa, że o stopniu integracji decydują wspólne wartości, normy społeczne oraz identyfikacja $\mathrm{z}$ grupą, wyrażająca się poczuciem przynależności. Zdaniem tego autora, system wartości stanowi sedno integracji ${ }^{4}$. Integrację konstytuują więc: wartości - ich urzeczywistnianie; zbiorowość, w której panują stosunki nieantagonistyczne; wspólne wzory działania, wspólne cele, wspólne ideały; zharmonizowanie elementów szczegółowych w spójną całość. $Z$ tego, co zostało wyżej wskazane, fundamentem integracji podmiotów edukacji muszą być stosunki społeczne, które będą cechować się dominacją racjonalnej przejrzystości, orientacją aksjologiczną, u podstaw której znajdować się będzie hierarchiczna struktura wartości wspomagająca

1 F.J. Lis, R. Lis, Integracja spoteczna, w: Encyklopedia aksjologii pedagogicznej, red. K. Chałas, A. Maj, Radom 2016, s. 435.

2 Encyklopedia Powszechna, Warszawa 1984, s. 291.

3 Zob. M. Winiarski, Wspótdziatanie szkoty i środowiska, Warszawa 1992, s. 34.

4 W. Jacher, Zagadnienia integracji systemu spotecznego, Warszawa 1976, s. $100-101$. 
osiąganie pełni człowieczeństwa osoby, akceptacją swobodnej ekspresji osobowości, akceptacją i promocją indywidualności ,,zanurzonej” $\mathrm{w}$ dobro indywidualne zintegrowane $\mathrm{z}$ dobrem wspólnym, promocją wzorów osobowych godnych naśladowania.

W literaturze, zwłaszcza socjologicznej, wyróżnia się cztery rodzaje integracji:

- kulturową,

- normatywną,

- funkcjonalną,

- komunikacyjną.

Integracja kulturowa oznacza zgodność, harmonię między wartościami a normami kulturowymi, czyli między elementami kulturowymi o różnym stopniu zróżnicowania. Chodzi tu o jedność rzeczywistości (o charakterze pluralistycznym), przy uwzględnieniu różnorodności wątków i przy zachowaniu konsensusu co do zasady czy zasad podstawowych, wyznaczających granice tożsamości kulturowej ${ }^{5}$.

Franciszek J. Lis i Robert Lis zwracają uwagę, że „w systemie zorganizowanym horyzontalnie działania jego członków przebiegają w warunkach równości i wspólnoty, nie polegają wówczas na zdobywaniu czegoś na innych czy wbrew innym i wspólnie z innymi. Istotne znaczenie przypisuje się racjonalności powiązań elementów kultury, która odnosi się do logiczności, niesprzeczności i koherentności, między innymi systemów i norm”.

Powyżej wskazany rodzaj integracji stanowi „rdzeń” wychowania w kulturze środowiska i budowania kultury środowiska. Idea powiązania szkoły z kulturą środowiska znajduje odbicie w pracach Komitetu Ekspertów do spraw Edukacji Narodowej, kierowanego przez Czesława Kupisiewicza. Autorzy raportu podkreślają, że szkoła musi być otwarta na własne środowisko i budować w nim wielorakie więzi społeczne. Szkole przypisują oni funkcje kulturalne i opiekuńcze w stosunku do środowiska.

Idea ta znajduje odzwierciedlenie w katolickiej myśli społecznej, według której „,szkoła stanowi jakby pewne centrum, w którego wynikach i osiągnięciach powinny uczestniczyć równocześnie rodziny,

5 Zob. M. Winiarski, Wspótdziatanie szkoty i środowiska jako droga do uspotecznienia szkoty, „Edukacja” 1990, nr 2, s. 35.

$6 \quad$ F.J. Lis, R. Lis, Integracja spoteczna, dz. cyt. s. 438. 
nauczyciele, różnego rodzaju organizacje rozwijające życie kulturalne, obywatelskie, religijne, państwowe i całą społeczność”. Wielu pedagogów (E. Trempała, M. Jakowicka, M. Winiarski, S. Kowalski, J. Szczepański, W. Wroczyński) prezentuje stanowisko o konieczności wielostronnego powiązania edukacji z kulturą środowiska, wykorzystania środowiska jako naturalnego terenu działalności dydaktyczno-wychowawczej do mobilizowania sił społecznych tego środowiska, do realizacji zadań edukacyjnych poprzez różnorodne formy współpracy z rodziną, placówkami wychowania pozaszkolnego, organizacjami oraz instytucjami.

Integracja normatywna rozumiana jest jako ,stopień zdolności wartości i norm, którymi kierują się poszczególni członkowie grupy z normami i wartościami akceptowanymi w danej grupie lub społeczności”. F.J. Lis i R. Lis zwracają uwagę, że ,integracja normatywna jest ściśle związana $z$ integracją kulturową, obie dotyczącą wartości i norm społecznych. Różnica polega na nieco innym rozłożeniu akcentów. O ile w integracji kulturowej akcent pada głównie na powiązania między różnymi elementami kultury, o tyle w integracji normatywnej akcent ten zostaje przesunięty na relacje między wartościami i normami danego systemu a osobowościami i zachowaniami jego członków" ". Zatem istnienie jednolitego systemu wartości i wzorów postępowania wobec spraw wspólnych, jednolita opinia w tym względzie, stanowi podstawę tego typu integracji. „Trwałości integracji systemu najpełniej służy, poziom autonomicznego przyswajania systemu wartości i norm społecznych, które wchodzą w skład mentalności jednostki przez praktykę i doświadczenie w procesie socjalizacji i wychowania. Osoba przestrzega daną normę, gdyż uważa ją za słuszną i przekonana jest o jej zgodności ze swoim systemem wartości. $\mathrm{Z}$ powodu jej nieprzestrzegania przeżywa tzw. wyrzuty sumienia, ma poczucie, że postępuje nieetycznie. Im wyższy jest poziom integracji danego systemu społecznego, tym więcej jego członków i częściej zachowuje się zgodnie $\mathrm{z}$ ukształtowanym w ich osobowościach

7 Sobór Watykański II 1986, Konstytucje. Dekrety. Deklaracje, Poznań 2002, s. 318.

8 J. Turowski, Socjologia. Mate struktury spoteczne, Lublin 1993, s. 131.

$9 \quad$ F.J. Lis, R. Lis, Integracja spoteczna, dz. cyt., s. 438. 
autonomicznym systemem wartości i norm" ${ }^{10}$. Odnosząc problem integracji społecznej do współczesnej szkoły należy podkreślić, że w zamiarach reformatorów szkoła ma być szkołą wychowującą. Nie ma wychowania bez wartości. Budowanie aksjologicznej podstawy dla funkcjonowania szkoły staje się priorytetowym zadaniem. Podstawowym czynnikiem realizacji tego zadania jest integracja normatywna, która warunkuje budowanie i urzeczywistnianie właściwych struktur hierarchicznych, gwarantujących integralny rozwój i wychowanie człowieka w drodze dialogu, a także w autonomicznych, podmiotowych działaniach.

Integracja funkcjonalna występuje w sytuacji umiejętnego i sprawnego współdziałania w zakresie realizacji, przez daną zbiorowość, określonych zadań, sposobów ich realizowania, urzeczywistnianych przez nie wartości i norm. Dotyczy więc urzeczywistniania wartości systemu. Warunkiem urzeczywistniania jest stworzenie optymalnych warunków do wykonywania zadań, które ostatecznie mają aksjologiczny charakter. W integracji funkcjonalnej aspekt aksjologiczny zawiera się w realizacji wartości, wyrażających się w zachowaniach ludzkich, na różnych poziomach struktur społecznych. $\mathrm{Na}$ uwagę w tym względzie zasługują organizacja i zarządzanie zasobami ludzkimi ${ }^{11}$.

Integracja komunikatywna sprowadza się do sprawnego wzajemnego porozumiewania się, wymiany poglądów i ich uzgadniania w ramach określonej zbiorowości, poprzez różne formy komunikacji międzyludzkiej, jej kody i systemy informacyjne, zawierające określone wartości i normy ${ }^{12}$. Ten ostatni rodzaj integracji jest powiązany $\mathrm{z}$ wyżej wymienionymi rodzajami integracji: kulturową, normatywną, funkcjonalną, zaś ogniwem integrującym są wartości. Znajduje on swe miejsce w integracji kulturowej, ,ponieważ powiązania między wartościami ich upowszechnianie i dyfuzja są możliwe jedynie przez swój refleks w różnych komunikatach"13. Biorąc pod uwagę integrację normatywną należy podkreślić, że ,,stosunek jednostek do tych wartości i norm, ich internalizacja w procesie socjalizacji

10

11

12

13

Tamże, s. 439.

Tamże.

F.J. Lis, R. Lis, Integracja spoteczna a wartości, Lublin 1987, s. 8.

F.J. Lis, R. Lis, Integracja spoteczna, dz. cyt., s. 438. 
i wychowania wyraża się w różnych formach komunikacji”"14. U podstaw działań człowieka, które sprowadzają się do urzeczywistniania wartości, znajduje się komunikacja. Bez niej nie można budować życia społecznego.

\section{Integracja podmiołów szkoły - wybrane priorytetowe zadanie}

Integracja społeczna ze swej natury ma aksjologiczny charakter. Wartości stanowią jej podstawowy filar, warunkują jej stopień dojrzałości. Z drugiej zaś strony, przez integrację społeczną budowana jest przestrzeń aksjologiczna, w której funkcjonują pojedyncze osoby, jak również grupy i wspólnoty społeczne.

Czynnikami warunkującymi stopień integracji systemu są:

- „stawianie i realizowanie celów i zadań;

- utrzymanie i wzmacnianie wewnętrznej spójności;

- rozwijanie stosunków ze środowiskiem zewnętrznym;

- rozładowywanie powstających napięć i konfliktów"15.

Powstaje zasadnicze pytanie, w jakich obszarach pracy szkoły, w jej wiodących celach i zadaniach, wyrasta pilna potrzeba integracji podmiotów edukacji, by pełniej realizować funkcje szkoły, a tym samym budować przestrzeń rozszerzającego się horyzontu aksjologicznego.

Poniżej zostaną skrótowo zarysowane trzy wiodące zadania, do których zaliczamy:

- integrację wokół realizacji nadrzędnego celu szkoły;

- integrację na rzecz budowania szkoły środowiskowej;

- integrację wspomagającą edukację obywatelską.

Nadrzędnym celem polskiej szkoły, zawartym w Podstawie Programowej, jest integralny rozwój ucznia. Nie ma wychowania bez odpowiedzi na pytanie: kim jest człowiek. Ustawodawca nie określił w nadrzędnym celu szkoły, kim jest uczeń. Należy podkreślić, że w Podstawie Programowej, określanej potocznie jako podstawa ministra Handkego, mieliśmy czytelność w tej sprawie. Nadrzędnym celem szkoły był integralny rozwój osoby ucznia. Pojawia się więc potrzeba integracji podmiotów edukacji na rzecz przywrócenia antropologicznej podstawy wychowania. Realizacja tego celu wymaga

14 Tamże, s. 439.

15 Tamże, s. 435. 
przyjęcia określonej teorii integralnego wychowania. Do uznanych $\mathrm{w}$ pedagogice teorii należy warstwicowa teoria integralnego rozwoju i wychowania człowieka Stefana Kunowskiego. Teoria ta zakłada, że ,czynniki wewnętrzne (geniczne) są zróżnicowane rodzajowo i spontanicznie dochodzą do głosu we właściwym dla siebie czasie i w ustalonej kolejności tworząc różne podłoża wychowania, w których zachodzą tak zmiany ilościowe, jak potem dojrzewanie jakościowe”16. We wszechstronnym rozwoju człowieka wyróżnia pięć odrębnych warstw. Są to warstwy:

- biologiczna, tworząca nasz organizm;

- psychologiczna, rozwijająca całokształt psychiki;

- socjologiczna, formująca osobę społeczną wychowanka;

- kulturotwórcza, kreująca aktywnego twórcę kultury;

- czysto duchowa lub światopoglądowa, kształtująca w pełni duchowość i jej stronę duchowo-moralną ${ }^{17}$.

W każdej z tych warstw bytują określone dynamizmy warunkujące wpływy wychowawcze. Warstwie biologicznej autor przypisuje dynamizm - bios, warstwie psychologicznej - logos, socjologicznej etos, kulturotwórczej - agos, warstwie duchowej - los. Z punktu widzenia znaczenia $\mathrm{w}$ integralnym rozwoju integracji podmiotów edukacji, na uwagę zasługują funkcje agosu w zakresie zaspokajania potrzeb stałych oraz rozwojowych.

Funkcje te, przypisane do poszczególnych warstw, przedstawiają się następująco:

- sanare - opieka wychowawców nad biosem wychowanka i zdrowiem organizmu;

- edocere - wszechstronne wychowanie umysłowe;

- educere - ochrona wychowawcza nad działaniem etosu, czyli życiem społecznego środowiska;

- educare - opieka nad duchowością wychowanka i skierowanie go do ideału;

- christianisare - wtajemniczenie i przygotowanie wychowanka na spotkanie z Bogiem, Jezusem Chrystusem (wychowanie chrystocentryczne) ${ }^{18}$.

S. Kunowski, Podstawy wspótczesnej pedagogiki, Warszawa 2004, s. 195.

Zob. tamże, s. 197.

18 Zob. tamże, s. 248-250. 
W świetle zaproponowanej teorii powstaje pytanie: gdzie znajduje swe miejsce integracja społeczna i jakie może pełnić funkcje? Otóż łatwo zauważyć, że poszczególne rodzaje integracji są niejako w sposób naturalny związane z poszczególnymi funkcjami.

Integracja normatywna wpisuje się w funkcje educere i edocere; integracja kulturowa $\mathrm{w}$ funkcje educare, integracja komunikacyjna i funkcjonalna przenikają wszystkie funkcje.

Podstawowym warunkiem integralnego rozwoju jest urzeczywistnianie wartości ,,przypisanych” ze swej natury do poszczególnych warstw. Ich strukturę przedstawia poniższa tabela ${ }^{19}$.

\begin{tabular}{|c|c|c|}
\hline Lp. & Rodzaj warstwy & Rodzaj wartości \\
\hline 1 & $\begin{array}{l}\text { Warstwa świato- } \\
\text { poglaqdowa }\end{array}$ & $\begin{array}{l}\text { Szczéście człowieka; wartości religijne: wiara w Boga, religia, nadzieja, } \\
\text { miłość, modlitwa, świętość }\end{array}$ \\
\hline 2 & $\begin{array}{l}\text { Warstwa } \\
\text { kulturologiczna } \\
\text { (kulturotwórcza) }\end{array}$ & $\begin{array}{l}\text { Wartości zawarte w sztuce, poezij, muzyce, plastyce; wartości określajqce } \\
\text { kulturę narodu, bytujace w tradycjach narodowych, pamięci historycznej, } \\
\text { kulturze ludowej }\end{array}$ \\
\hline 3 & $\begin{array}{l}\text { Warstwa } \\
\text { socjologiczna }\end{array}$ & $\begin{array}{l}\text { Wartości moralne - prawość, wierność, poczucie odpowiedzialności, poszano- } \\
\text { wanie prawdy, dobroć } \\
\text { Wartości społeczne - godność, Ojczyzna, naród, Kościół, patriotyzm, niepod- } \\
\text { ległość, praworzqdność, tradycia, wolność, pokói, tolerancja, sprawiedliwość, } \\
\text { równość społeczna, demokracja, solidarność } \\
\text { Wartości życia codziennego - rodzina, sumienność, uczciwość, honor, dom, } \\
\text { wspólnota, odpowiedzialność, posłuszeństwo, opanowanie, cierpliwość, odwa- } \\
\text { ga, koleżeństwo, czystość, samodzielność, umieiętność bycia sobq, lojalność, } \\
\text { wytrwałość, prawdomówność, praca, pracowitość, łagodność, ufność, uprzej- } \\
\text { mość, punkłualność, systematyczność, dyskrecia, szczerość, stałość przekonań, } \\
\text { szacunek, poszanowanie życia, pokora, przebaczenie, wyrzeczenie, jałmużna, } \\
\text { dobre obyczaje }\end{array}$ \\
\hline 4 & $\begin{array}{l}\text { Warstwa } \\
\text { psychiczna }\end{array}$ & wiedza, nauka, mqqdrość, odkrywczość, twórczość \\
\hline 5 & $\begin{array}{l}\text { Warstwa } \\
\text { biologiczna }\end{array}$ & $\begin{array}{l}\text { Wartości hedonistyczne - wolność, seks, zabawa } \\
\text { Wartości witalne - zdrowie, pokarm, powietrze, ruch, wypoczynek, wartości } \\
\text { geograficzno-przyrodnicze } \\
\text { Wartości materialne - wszystkie dobra materialne ułatwiajqce życie, } \\
\text { zapewniajqce egzystencię, pieniqqdze, mieszkanie, środki lokomocii, sprzęt } \\
\text { techniczny }\end{array}$ \\
\hline
\end{tabular}

19 Schemat ten jest wykorzystywany w wielu moich opracowaniach. Zob. K. Chałas, Wartości w programie wychowawczym szkoty stużace integralnemu rozwojowi i wychowaniu ucznia, Warszawa 2017. 
Urzeczywistnianie powyżej wskazanej struktury wymaga zespolenia sił uczniów, nauczycieli, rodziców, przedstawicieli społeczno-kulturowego środowiska lokalnego. Przedmiotem integracji będzie poszukiwanie wiedzy o wartościach, prowadzenie dialogu na temat funkcji wartości w życiu człowieka, poszukiwanie sposobów urzeczywistniania wartości, podejmowanie działań aksjologicznych.

Wskazana wyżej struktura powinna stać się aksjologiczną płaszczyzną integracji podmiotów szkoły. Scalenie różnorodnych działań w powyższym kontekście będzie stanowić o sile integracji uczniów, nauczycieli, rodziców, innych osób związanych ze szkołą. W ten oto sposób istnieje szansa pełnej realizacji nadrzędnego celu szkoły, jakim jest integralny rozwój ucznia.

Drugą ważną płaszczyzną budowania integracji podmiotów szkoły jest przekształcenie jej w szkołę środowiskową $\mathrm{Na}$ istotę integracji w wychowaniu środowiskowym zwraca uwagę Mikołaj Winiarski. Dokonując analizy znaczeń pojęć „,integracja”, „integrować”, „integralny”, przez integrację (jako swoisty typ czynności) rozumie on scalanie różnorodnych działań opiekuńczo-wychowawczych w pewną całość, gwarantującą optymalizację celów wychowawczych. A więc integracja będzie tu niezbędnym warunkiem skutecznego działania opiekuńczo-wychowawczego ${ }^{20}$.

Należy przy tym podkreślić, że ten sam autor uważa integrację funkcjonalną za główny, najbardziej znaczący typ integracji, a przez to priorytetowy, fundamentalny kierunek działalności środowiskowej w rejonie zamieszkania. Na potwierdzenie tego stanowiska przytacza następujące argumenty:

- znaczna część elementów integracji normatywnej i komunikatywnej zawiera się w integracji funkcjonalnej. Te dwa typy integracji stanowią sui generis warunki skuteczności integracji funkcjonalnej,

- integracja funkcjonalna (przejawiająca się we współdziałaniu) z natury jest bliska pedagogii społecznej i teorii wychowania. Rozpatrywana jest jako znaczący czynnik (środek) optymalizacji działalności społeczno-wychowawczej, 
- współdziałanie powiązane organicznie z koordynacją stanowi podstawowy kierunek działalności integracyjnej ${ }^{21}$.

Integracja traktowana jest jako cecha konstytutywna każdego systemu wychowania (także mikrosystemu szkolnego), a niezbędnym warunkiem rozwoju szkoły jako mikrosystemu wychowawczego jest współdziałanie ze środowiskiem. Współdziałanie zaś jest czynnikiem sprawczym integracji ${ }^{22}$.

We współpracy szkoły i środowiska omawiany autor wyróżnia następujące zasady:

- oddolnej inicjatywy i dobrowolności,

- równorzędności i poszanowania partnerów,

- kompleksowości i współpracy,

- korelacji celów i działań,

- autentyczności celów i zadań,

- planowości współpracy,

- ciągłości i systematyczności,

- elastyczności i różnorodności form oraz metod działania,

- zasada innowacyjności w pracy środowiskowej,

- stopniowego poszerzania zakresu współdziałania ${ }^{23}$.

Biorąc pod uwagę włączanie środowiska społecznego szkoły w proces wychowawczo-dydaktyczny należy podkreślić, że „systemy rozwojowe, dojrzałe siłą swojej integracji wykazują większe skłonności nie do wykluczenia elementów dysfunkcjonalnych i neutralnych, ale wspieranie ich uczestnictwa. Elementy te mogą stymulować system do reprodukowania i kreowania funkcjonalnych sił oraz mechanizmów zabezpieczających jego dynamiczną równowagą, a także efektywność rozwojową. (...) Istotne jest doskonalenie spójności strukturalnej i funkcjonalnej przez pozytywne asymilowanie destrukcyjnych i neutralnych działań oraz sił wewnątrzsystemowych jak i zewnętrznych" 24 .

Implikuje to określone zadania dla podmiotów edukacji:

- budowanie wspólnoty stwarzającej szansę rozwijania podmiotowości i tożsamości osobowościowej jej członków;

Zob. tamże, s. 65.

Zob. tamże, s. 35.

Zob. tamże, s. 11.

24 Zob. F.J. Lis, R. Lis, Integracja spoteczna, dz. cyt., s. 436. 
- stwarzanie szans rozwijania pełni człowieczeństwa poprzez urzeczywistnianie wspólnych wartości, celów, podejmowanie działań.

Ideą przewodnią jest współdecydowanie przez uczniów, nauczycieli, rodziców, jakie problemy środowiskowe staną się przedmiotem nauczania i pracy nad ich rozwiązaniem. W ten sposób w toku pogłębionego rozumienia stwarzane są możliwości działań konstruktywnych i własnego rozwoju, kreowania tożsamości.

Zasadność stosowania tak rozumianej integracji znajduje swoje odzwierciedlenie w stanowisku, że tożsamość kulturowa w małej ojczyźnie musi być postrzegana w perspektywie kulturowej tożsamości ogólnoludzkiej, gdyż w przeciwnym wypadku następuje zerwanie ciągłości i dialogu z ,innym”, czasem „obcym”.

Rozpatrując integrację podmiotów edukacji należy podkreślić ważną kwestię, a zarazem zadanie, które sprowadza się do utrzymania $\mathrm{w}$ systemie szkoły dynamicznej równowagi jedności w różnorodności ${ }^{25}$.

Budowanie szkoły środowiskowej poprzez integrację jej podmiotów powinno uczynić punktem wyjścia świat wartości ucznia, jego doświadczenia. Jak zauważa Renata Nowakowska-Siuta, ,zwiększa to poczucie bezpieczeństwa w przechodzeniu od tego co znane, do tego co nieznane. Wychodząc od teraźniejszości dziecka, zmniejszamy rozbieżność pomiędzy nabytą $\mathrm{w}$ przeszłości wiedzą a przyszłością, w której dziecko będzie rzeczywiście tej wiedzy potrzebować, orientacja na przyszłość, a nie wyłącznie na przeszłość umożliwia nadanie kierunku wiedzy dziecka za pomocą aktualnie toczących się wydarzeń naukowych, społecznych, obyczajowych etc." ${ }^{26}$.

Trzecim obszarem, w którym integracja podmiotów edukacji może mieć swój wyraz jest edukacja obywatelska. Integracja w tym zakresie odgrywa podwójną funkcję. Z jednej strony stanowi „mikro-szkołę" edukacji obywatelskiej, z drugiej zaś jest istotnym czynnikiem zewnętrznym inspirującym do działań na rzecz obywatelstwa. Integracja podmiotów edukacji powinna być zorientowana na:

Zob. tamże, s. 435.

R. Nowakowska-Siuta, Kamień na kamieniu - o zasadzie kompletności w pracy szkoty, w: Szkota w metaforze militarnej. Co w zamian, red. M. Dudzikowa, S. Jaskulska, Warszawa 2016, s. 215. 
I. Rozwój świadomości jednostkowej, społecznej, obywatelskiej, politycznej:

- zdobycie wiedzy antropologiczno-filozoficznej; odpowiedź na pytania: kim jest człowiek?, dokąd zmierza?, kim może się stać?, kim powinien się stać?;

- zdobycie wiedzy o obowiązkach i prawach człowieka;

- zdobycie wiedzy o instytucjach społecznych, państwowych, pozarządowych;

- analiza warunków sprzyjających integralnemu rozwojowi człowieka; zrównoważonemu rozwojowi;

- zdobycie wiedzy o konstytucji i innych kluczowych aktach prawnych o randze państwowej;

- promowanie wartości dziedzictwa kulturowego i historycznego o zasięgu lokalnym, regionalnym, krajowym, europejskim;

- promowanie szacunku dla innych kultur narodowych, etnicznych.

II. Rozwijanie myślenia krytycznego, kształtowanie postaw, urzeczywistniane wartości:

- kształtowanie umiejętności potrzebnych do aktywnego uczestnictwa w życiu społecznym:

- otwartość na drugiego człowieka i traktowanie go jako celu a nie środka;

- umiejętność i sprawność komunikowania się;

- umiejętność współpracy z drugim człowiekiem, grupą, wspólnotą;

- odpowiedzialność za siebie i drugiego człowieka, grupę, wspólnotę;

- umiejętność radzenie sobie w sytuacjach problemowych i stresowych;

- gotowość do działalności dobrowolnej w różnego rodzaju organizacjach;

- zaangażowanie w podejmowane zadania;

- przejawianie postawy innowacyjnej.

- kształtowanie szacunku dla siebie i innych/szanowanie godności własnej i drugiego człowieka w celu wzajemnego zrozumienia; 
- urzeczywistnianie odpowiedzialności indywidualnej, społecznej i moralnej;

- wzmacnianie ducha solidarności w celu budowania więzi społecznych/wspólnotowych/grupowych;

- wychowanie ku wartościom osobowym, społecznym, moralnym, kulturowym z uwzględnieniem różnych perspektyw społecznych w świetle obiektywizmu aksjologicznego i odniesienia personalnego (podmiotowego);

- kształtowanie postawy przyjaźni, pozytywnego nastawienia do drugiego człowieka;

- kształtowanie umiejętności pokojowego rozwiązywania konfliktów;

- kształtowanie postawy proekologicznej, wyrażającej się troską o środowisko na rzecz zrównoważonego rozwoju;

- kształtowanie bardziej aktywnych strategii zwalczania rasizmu i ksenofobii.

III. Promowanie aktywnej partycypacji uczniów:

- stwarzanie szans aktywności poprzez włączanie się w działania społeczności szkolnej, lokalnej, narodowej i międzynarodowej;

- stwarzanie szans nabywania doświadczeń demokratycznych w szkole;

- tworzenie grup i wspólnot uczniowskich ${ }^{27}$.

W tak ujętą edukację obywatelską ,wpisuje” się edukacja aksjologiczna i wychowanie ku wartościom. Podstawę aksjologiczną tworzą cztery kręgi wartości:

- wartości „opisujące” osobę ludzką;

- wartości warunkujące integralny rozwój człowieka;

- wartości środowiska, w którym człowiek żyje i funkcjonuje;

- wartości stanowiące europejską wspólnotę ducha.

W szerokim ujęciu celem edukacji obywatelskiej jest nie tylko zdobycie przez uczniów wiedzy o społeczeństwie, ale także zrozumienie rzeczywistości społecznej oraz rozwijanie/zwiększanie zdolności

27 Por. E. Potulicka, Wychowanie obywatelskie - nowy przedmiot nauczania w Anglii, w: Wychowanie. Pojęcia. Procesy. Konteksty, t. 4, red. M. Dudzikowa, M. Czerepaniak-Walczak, Gdańsk 2008, s. 58. 
do uczestnictwa w życiu społecznym. Centrum jej stanowią więc: wiadomości, umiejętności, wyznawane wartości i postawy ${ }^{28}$.

Eugenia Potulicka na podstawie analiz angielskiej literatury wskazuje trzy kategorie edukacji obywatelskiej:

- edukacja o obywatelstwie - przekazanie odpowiedniej wiedzy, rozumienie historii narodowej, znajomość struktur władzy, procesów rządzenia i życia politycznego.

- edukacja poprzez obywatelstwo - nabywanie doświadczeń, uczenie się poprzez działanie, aktywne uczestnictwo w społeczności szkolnej, lokalnej oraz ponadlokalnej.

- edukacja dla obywatelstwa - wyposażenie uczniów w zestaw narzędzi (wiedzę, rozumienie, umiejętności, postawy, wartości) umożliwiających im aktywne oraz sensowne pełnienie ról i wypełnianie odpowiedzialności, które wymaga dorosłe życie ${ }^{29}$.

Założenie dotyczące obywatelstwa brzmi: powyższa edukacyjna triada powinna znaleźć swe miejsce w procesie wychowawczo-dydaktycznym. W kontekście tematu niniejszego opracowania na szczególną uwagę zasługuje edukacja dla obywatelstwa. Łączy ona nierozerwalnie wartości i wiedzę oraz umiejętności, wśród których znaczące miejsce zajmują umiejętności służące odgrywaniu aktywnej roli w społeczeństwie na poziomie lokalnym, ponadlokalnym, narodowym, międzynarodowym. Wiążą się one z umiejętnościami społecznymi. Wśród nich na szczególną uwagę zasługują umiejętności słuchania, ujmowania zagadnień w sposób strukturalny, rozpoznawania i formułowania problemów, rozpoznawania wartości i budowania aksjosfery poprzez ich urzeczywistnianie, dyskutowanie, debatowanie, animowanie społeczności do działań społeczno-obywatelskich, organizowanie działań, wartościowanie efektów i na ich podstawie budowanie kolejnych programów działalności obywatelskiej ${ }^{30}$.

Tak rozumiana edukacja obywatelska integralnie łączy:

- „odpowiedzialność społeczną i moralną;

- zaangażowanie w działalność wspólnotową;

- świadomość polityczną"31.

Zob. tamże, s. 40.

Zob. tamże.

Por. tamże, s. 43.

31 Tamże. 
Należy przy tym podkreślić, że tak ujęta edukacja obywatelska wprowadza uczniów w przestrzeń wartości społecznych, moralnych, kulturowych - w ich doświadczanie i urzeczywistnianie.

Szkoła jest ważnym podmiotem edukacji obywatelskiej. Jej działalność w tym zakresie powinna koncentrować się głównie na „zdobywaniu przez jej podmioty (uczniów, nauczycieli, rodziców) wiedzy i umiejętności obywatelskich poprzez doświadczenia i praktykowanie działań obywatelskich, rozwiązywanie konkretnych problemów społecznych i lokalnych, czy wręcz uczestniczenie w instytucjach partycypacji obywatelskiej (choć zacząć należy po prostu od reaktywowania autentycznego samorządu uczniowskiego i szkolnego oraz urealnienia pracy rad rodziców, co nie dokona się bez przyznania wszystkim tym instytucjom odpowiednich kompetencji)"32.

Drugim ważnym zadaniem jest współpraca szkoły ze środowiskiem społeczno-kulturowym (samorząd lokalny, organizacja społeczna, media). Chodzi o włączanie młodzieży w realizację programów instytucjonalnych oraz opracowywanie przez szkołę projektów działalności społeczno-obywatelskiej i włączania w ich realizację instytucji lokalnych i pozalokalnych ${ }^{33}$.

W powyższym kontekście na uwagę zasługują programy:

- szkoła w środowisku - aktywnie włączająca się w realizację programów;

- szkoła dla środowiska - oferująca projekty edukacji obywatelskiej.

Trzecim zadaniem są staże aktywacyjne młodzieży: w lokalnych mediach, organizacjach pozarządowych, instytucjach samorządo$w_{y c h}{ }^{34}$. Ta forma edukacji obywatelskiej nawiązuje do praktyk uczniowskich prowadzonych w historii polskiej oświaty. $\mathrm{W}$ tym względzie ważna jest oddolna inicjatywa, zaufanie, troska, solidarność, odpowiedzialność, twórcze podejście do problemów.

„Edukacja obywatelska powinna (...) polegać na przekazywaniu pewnego zakresu wiedzy teoretycznej, wiedzy 'stosowanej' i doświadczeń praktycznych oraz tego, co określić można jako proces wychowania do wartości (formacja). Teoria musi być przekazywana

\footnotetext{
32 Tamże, s. 198.

33 Zob. tamże.

34 Zob. tamże.
} 
w sposób w miarę syntetyczny i prosty (odchudzanie programów), ale powinna obejmować także nowoczesne podstawy wiedzy na temat sektora pozarządowego (na przykładzie roli tego sektora w demokracji, idei ekonomii społecznej, czy zasady pomocniczości). Edukacja 'stosowana' powinna kształcić rozmaite obywatelskie umiejętności praktyczne uczniów, uczyć przez doświadczenie sprawnego dialogu, mediacji, poruszania się w świecie instytucji demokratycznych czy rozwiązywania różnorodnych zadań obywatelskich"35.

W powyższym kontekście integracja społeczna podmiotów edukacji jest trajektorią edukacji obywatelskiej, warunkującej kształtowanie świadomych i aktywnych obywateli.

Przedstawiony materiał nie wyczerpuje zagadnienia podjętego $\mathrm{w}$ temacie, zaledwie je sygnalizuje. Integrację podmiotów szkoły środowiskowej szeroko ujęłam w dwóch pozycjach: W poszukiwaniu szkoty wiejskiej, Lublin 1997; W poszukiwaniu tożsamości szkoty wiejskiej, Rzeszów 1994 - z nich zaczerpnięto fragmenty do przedstawionego opracowania. Zagadnienie edukacji obywatelskiej w szerszym ujęciu znajduje się w artykule pt. Przysztośc należy do świadomych obywateli. Jakie konsekwencje sq niezbędne świadomemu i aktywnemu obywatelowi? Jak skutecznie je ksztattować? (Perspektywa aksjologiczna), w: S.M. Kwiatkowski, Kompetencje przysztości, Warszawa 2018 (wykorzystano fragmenty). Zagadnienie integralnego rozwoju i wychowania szerzej zostało opisane w książce pt. Wychowanie ku wartościom wiejskim jako szansa integralnego rozwoju ucznia, Lublin 2007. Integracja podmiotów edukacji w perspektywie aksjologicznej wymaga gruntowanego opracowania teoretycznego i szerokich badań empirycznych.

\section{Bibliografia}

Chałas K., Przysztość należy do swiadomych obywateli. Jakie konsekwencje sq niezbędne świadomemu i aktywnemu obywatelowi? Jak skutecznie je ksztattować? (Perspektywa aksjologiczna), w: S.M. Kwiatkowski, Kompetencje przysztości, Wydawnictwo Fundacji Rozwoju Systemu Edukacji, Warszawa 2018.

35 Tamże, s. 199-200. 
Chałas K., W poszukiwaniu pedagogii szkoty wiejskiej, Wydawnictwo PL, Lublin 1997.

Chałas K., W poszukiwaniu tożsamości szkoty wiejskiej, „Fosze”, Rzeszów 1994.

Chałas K., Wartości w programie wychowawczym szkoty stużace integralnemu rozwojowi i wychowaniu ucznia, ORE, Warszawa 2017.

Chałas K., Wychowanie ku wartościom wiejskim jako szansa integralnego rozwoju ucznia, Wydawnictwo KUL, Lublin 2007.

Encyklopedia Powszechna, PWN, Warszawa 1984.

Jacher W., Zagadnienia integracji systemu spotecznego, PWN, Warszawa 1976.

Kunowski S., Podstawy wspótczesnej pedagogiki, Wydawnictwo Salezjańskie, Warszawa 2004.

Lis F.J., Lis R., Integracja spoteczna, w: Encyklopedia aksjologii pedagogicznej, red. K. Chałas, A. Maj, Polwen, Radom 2016, s. 435-440.

Lis F.J., Lis R., Integracja spoteczna a wartości, Wydawnictwo UMCS, Lublin 1987.

Nowakowska-Siuta R., Kamień na kamieniu-o zasadzie kompletności w pracy szkoty, w: Szkota w metaforze militarnej. Co w zamian, red. M. Dudzikowa, S. Jaskulska, Wolters Kluwer, Warszawa 2016.

Potulicka E., Wychowanie obywatelskie - nowy przedmiot nauczania w Anglii, w: Wychowanie. Pojęcia. Procesy. Konteksty, t. 4, red. M. Dudzikowa, M. Czerepaniak-Walczak, Gdańskie Wydawnictwo Psychologiczne, Gdańsk 2008, s. 37-53.

Sobór Watykański II 1986. Konstytucje. Deklaracje. Dekrety, Pallottinum, Poznań 2002.

Turowski J., Socjologia. Mate struktury spoteczne, Wydawnictwo UMCS, Lublin 1993.

Winiarski M., Wspótdziatanie szkoty i środorwiska jako droga do uspotecznienia szkoty, „Edukacja” 1990, nr 2, s. 32-35.

Winiarski M., Wspótdziatanie szkoty i środowiska, Wydawnictwo UW, Warszawa 1992.

\section{ADRES DO KORESPONDENCJI}

Prof. dr hab. Krystyna Chałas

Katolicki Uniwersytet Lubelski Jana Pawła II

Wydział Nauk Społecznych

Instytut Pedagogiki

e-mail:kryschal@kul.lublin.pl 